\title{
Ergonomyc
}

\section{PENGUKURAN POSTUR KERJA PADA OPERATOR PRODUKSI PENGADUKAN AMPAS MASAK MENGGUNAKAN METODE WERA DI UD. KILANG MINYAK HIDUP BARU}

\author{
Cut Ita Erliana* \\ Jurusan Teknik Industri, Fakultas Teknik, Universitas Malikussaleh, Aceh, Indonesia \\ *Corresponding Author: cutitha@unimal.ac.id
}

\begin{abstract}
Abstrak - UD. Kilang Minyak Hidup Baru merupakan perusahaan yang bergerak di bidang pengolahan kelapa menjadi minyak kelapa. UD. Kilang Minyak Hidup Baru memiliki banyak stasiun kerja yaitu stasiun penyimpanan bahan baku, stasiun parutan kelapa, stasiun perebusan, stasiun pengadukan ampas masak, dan stasiun press. Objek penelitian yang diambil yaitu di stasiun pengadukan ampas masak. Petugas yang diteliti berjumlah dua orang dengan jam kerja 8 jam perhari. Berdasarkan observasi, postur kerja operator termasuk dalam postur kerja berisiko namun belum pernah dilakukan pengukuran. Tujuan penelitian ini adalah untuk mengetahui hasil pengukuran postur kerja pengadukan ampas masak dengan menggunakan metode Workplace Ergonomic Risk Assesment (WERA). Hasil penelitian menunjukkan bahwa pengukuran postur kerja menggunakan metode WERA berada pada tingkat risiko medium. Tingkat risiko tersebut mengindikasikan bahwa dibutuhkan investigasi lebih lanjut dan perbaikan pada sistem kerja.
\end{abstract}

Kata Kunci: Ampas Masak, Ergonomi, Postur Kerja, WERA.

\section{Pendahuluan}

Provinsi Aceh merupakan daerah yang memiliki potensi pengembangan kelapa yang cukup besar. Luas area tanaman kelapa di Provinsi Aceh mencapai 102.671 Ha dengan hasil produksi sekitar 59.000 ton/tahun. Pada umumnya petani kelapa menjual kelapa dalam keadaan basah di pasar lokal. Pada saat panen raya, produksi kelapa melebihi kebutuhan lokal, sehingga banyak kelapa yang tidak termanfaatkan, yang menyebabkan harga kelapa menurun drastis. Hal ini tentu sangat merugikan petani kelapa, sehingga untuk meningkatkan taraf hidup dan ekonomi para petani pada pasca panen diperlukan penambahan produk pengolahan buah kelapa, salah satu produk pengolahan buah kelapa adalah sebagai bahan baku pembuatan minyak kelapa.

Salah satu minyak kelapa yang didapat dari pengolahan produk kelapa adalah minyak kelapa murni atau yang biasa disebut Virgin Coconut Oil (VCO). Dari segi ekonomi minyak kelapa murni mempunyai harga jual yang lebih tinggi dibanding minyak kelapa biasa yang diolah secara tradisional dengan memanaskan santan atau mengendapkan santan dalam waktu yang lama sehingga menghasilkan bau yang tengik akibat kadar air yang masih tinggi.

Minyak kelapa murni merupakan modifikasi proses pembuatan minyak kelapa sehingga dihasilkan produk dengan kadar air dan kadar asam lemak bebas yang lebih rendah, berwarna bening, berbau harum serta mempunyai daya simpan yang cukup lama yaitu 12 bulan. Penelitian ini dilakukan di UD. Kilang Minyak Hidup Baru terletak di Desa Paya Rangkuluh, Kecamatan Kuta Blang, Kabupaten Bireuen, Provinsi Aceh UD. Kilang Minyak Hidup Baru merupakan perusahaan yang bergerak di bidang pengolahan kelapa menjadi minyak kelapa. UD. Kilang Minyak Hidup Baru memiliki banyak stasiun kerja yaitu stasiun penyimpanan bahan baku, stasiun parutan kelapa, stasiun perebusan, stasiun pengadukan ampas masak, dan stasiun press. Objek penelitian yang diambil yaitu di stasiun pengadukan ampas masak. Petugas yang diteliti berjumlah dua orang dengan jam kerja 8 jam perhari.

Kondisi sikap kerja pada pengadukan ampas masak dianggap beresiko pada pekerja. UD. Kilang Minyak Hidup Baru yang seharusnya memperhatikan prosedur untuk membuat gerakan kerja yang memenuhi prinsip-prinsip 
ekonomi gerakan dan dengan memperhatikan kemampuan dan keterbatasan pekerja agar berkurangnya keluhan pekerja. Pengukuran yang dianggap beresiko ini diambil berdasarkan keluhan pekerja pada bagian pengadukan ampas masak ini banyak mengeluhkan tentang nyeri otot di leher, sakit pinggang, nyeri otot di pergelangan tangan dan kaki. Tujuan yang ingin dicapai dalam penelitian ini adalah untuk mengetahui hasil pengukuran postur kerja pengadukan ampas masak dengan menggunakan metode Workplace Ergonomic Risk Assesment (WERA).

\section{Tinjauan Pustaka}

\subsection{Ergonomi}

Istilah "ergonomi" berasal dari bahasa latin yaitu ergon (kerja) dan nomos (hukum alam) dan dapat didefinisikan sebagai studi tentang aspekaspek manusia dalam lingkungan kerjanya yang ditinjau secara anatomi, fisiologi, psikologi, engineering, manajemen dan desain perancangan. Ergonomi berkenaan pula dengan optimasi, efisiensi, kesehatan, keselamatan dan kenyamanan manusia di tempat kerja, di rumah dan tempat rekreasi. Di dalam ergonomi dibutuhkan studi tentang sistem dimana manusia, fasilitas kerja dan lingkungannya saling berinteraksi dengan tujuan utama yaitu menyesuaikan suasana kerja dengan manusia nya.

\subsection{Postur Kerja}

Postur kerja merupakan titik penentu dalam menganalisa keefektifan dari suatu pekerjaan. Apabila postur kerja yang dilakukan oleh operator sudah baik dan ergonomis maka dapat dipastikan hasil yang diperoleh oleh operator tersebut akan baik. Akan tetapi bila postur kerja operator tersebut tidak ergonomis maka operator tersebut akan mudah kelelahan. Apabila operator mudah mengalami kelelahan maka hasil pekerjaan yang dilakukan operator tersebut juga akan mengalami penurunan dan tidak sesuai dengan yang diharapkan (Susihono, 2012).

\subsection{Workplace Ergonomic Risk Assessment}

Metode (WERA) merupakan metode yang menjelaskan pengembangan penilaian resiko ergonomis tempat kerja guna mendeteksi faktor resiko fisik yang terkait sama gangguan WorkRelated Muculoskeletal Disorder (WMSDs) pada pekerja.

Metode WERA mempunyai sistem penilaian dan tingkat tindakan yang memberikan panduan terhadap resiko serta kebutuhan untuk melakukan penilaian yang lebih rinci. Dalam pelaksanaan konsep metode WERA memiliki beberapa langkah berikut: (Aliafahri, 2018):

1. Langkah pertama: Memastikan terdapat 9 faktor risiko fisik yang dapat dianalisis yaitu bahu, pergelangan tangan, punggung, leher, kaki, kekuatan, getaran, kontak stres, dan lamanya pekerjaan.

2. Langkah kedua: Menentukan penilaian terhadap operator mengenai 9 faktor risiko fisik sesuai dengan keadaan sebenarnya.

3. Langkah ketiga: Menghitung total skor akhir dengan cara menjumlahkan skor tiap penilaian faktor risiko.

4. Langkah keempat: Penentuan kategori action level berdasarkan total skor akhir akan menunjukkan apakah tingkat risiko tergolong low, medium, atau high.

Tabel 1. Indikator WERA

\begin{tabular}{|c|l|}
\hline Indikator & Resiko Fisik \\
\hline 1 & Shoulder \\
\hline 2 & Wrist \\
\hline 3 & Back \\
\hline 4 & Neck \\
\hline 5 & Leg \\
\hline 6 & Forceful \\
\hline 7 & Vibration \\
\hline 8 & Contact Stress \\
\hline 9 & Task Duration \\
\hline
\end{tabular}

Tabel 2. Resiko WERA

\begin{tabular}{|l|c|l|}
\hline Rank Level & Score & \multicolumn{1}{c|}{ Action } \\
\hline Low & 2 & $\begin{array}{l}\text { Mungkin diperlukan } \\
\text { perbaikan }\end{array}$ \\
\hline Medium & 4 & Diperlukan perbaikan \\
\hline High & 6 & $\begin{array}{l}\text { Segera diperlukan } \\
\text { perbaikan }\end{array}$ \\
\hline
\end{tabular}

\section{Metodelogi Penelitian}

Adapun skema yang dilakukan dalam melakukan penelitian yaitu berikut:

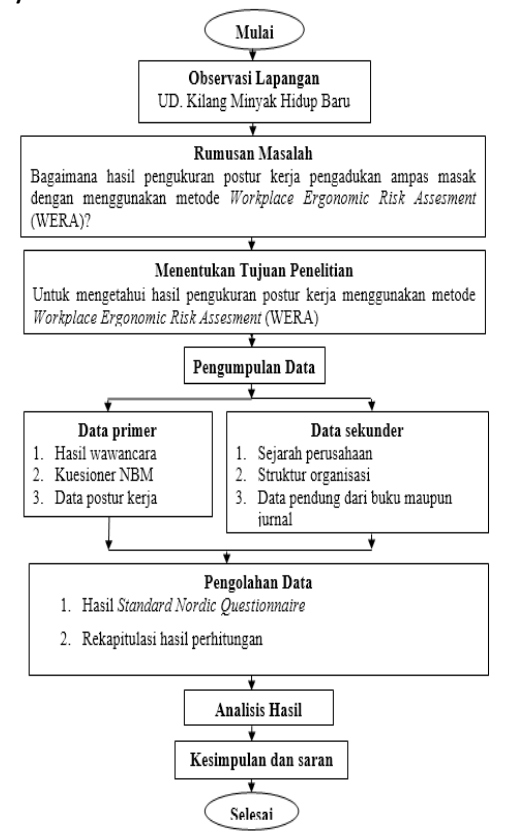

Gambar 1. Skema Metodelogi Penelitian 


\section{Hasil Dan Pembahasan}

Untuk menyelesaikan permasalahan pada perusahaan ini diperlukan data stasiun kerja, jumlah pekerja dan jam kerja serta dokumen aktivitas yang dilakukan. Berikut Data Stasiun Kerja di UD. Kilang Minyak Hidup Baru

Tabel 3. Data Stasiun Kerja

\begin{tabular}{|c|l|c|}
\hline No & \multicolumn{1}{|c|}{ Stasiun Kerja } & Jumlah Pekerja \\
\hline 1 & Penyimpanan Bahan Baku & 2 \\
\hline 2 & Parutan Kelapa & 1 \\
\hline 3 & Perebusan & 2 \\
\hline 4 & Pengadukan Ampas Masak & 2 \\
\hline 5 & Press & 3 \\
\hline
\end{tabular}

\section{Data Stasiun Kerja Pengadukan Ampas Masak}

Tabel 4. Data Stasiun Kerja Pengadukan Ampas Masak

\begin{tabular}{|c|l|c|c|}
\hline No & Pekerja & Usia & Lama Bekerja \\
\hline 1 & Mutaqin & 38 & 5 Tahun \\
\hline 2 & Sunardi & 25 & 2 Tahun \\
\hline
\end{tabular}

Data Jam Kerja di UD. Kilang Minyak Hidup Baru

Jumlah hari kerja dalam seminggu : 6 hari kerja Jumlah jam kerja per hari $\quad: 8$ jam kerja

Jam istirahat : Pukul 12.00-13.00 WIB

Jumlah shift $\quad: 1$

Shift $\quad$ : Pukul 08.00-17.00 WIB

\section{Data Kegiatan Pengadukan Ampas Masak}

Adapun gambar aktivitas pengadukan ampas masak stasiun 1 dapat dilihat pada Gambar 2 berikut:

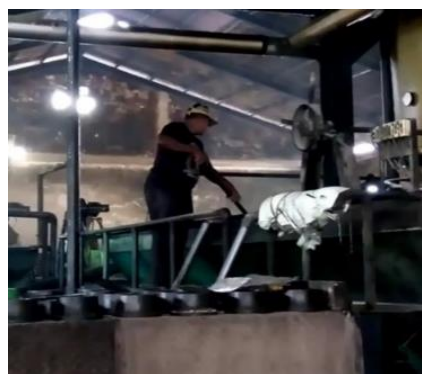

Gambar 2. Proses Pengadukan Ampas Masak Stasiun 1

gambar aktivitas pengadukan ampas masak stasiun 2 dapat dilihat pada Gambar 3 berikut:

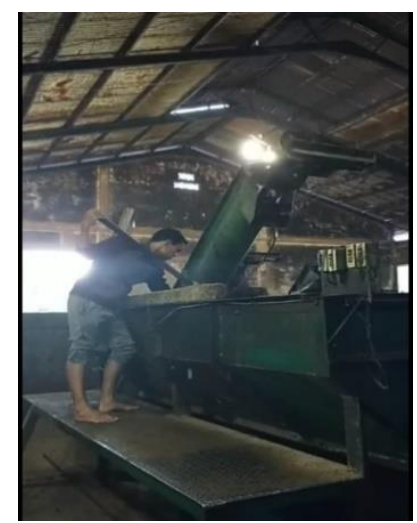

Gambar 3. Proses Pengadukan Ampas Masak Stasiun 2
Penilaian Aktivitas Pengadukan Ampas Masak Stasiun Penilaian postur kerja pada aktivitas pengadukan ampas masak berikut:

1. Penilaian Shoulder (bahu)

Gambar aktivitas pengadukan ampas masak dapat dilihat pada gambar 4 berikut:

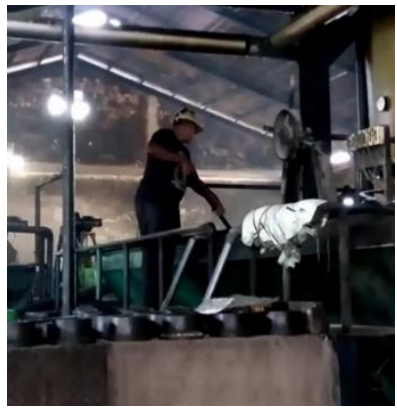

Gambar 4. Penilaian Shoulder

Cara pengambilan nilai tingkat risiko shoulder dapat dilihat pada Tabel 5 berikut:

Tabel 5. Penilaian Tingkat Risiko Shoulder Pekerja 1

\begin{tabular}{|c|l|l|l|l|}
\hline \multirow{4}{*}{ Shoulder } & \multicolumn{4}{|c|}{ Tingkat Risiko } \\
\cline { 2 - 5 } & \multirow{3}{*}{ Postur } & \multicolumn{1}{|c|}{ Low } & \multicolumn{1}{c|}{ Medium } & \multicolumn{1}{c|}{ High } \\
\cline { 2 - 5 } & $\begin{array}{l}\text { Bahu diposisi } \\
\text { netral }\end{array}$ & Bahu ditekuk & $\begin{array}{l}\text { Bahu ditekuk } \\
\text { keatas }\end{array}$ \\
\cline { 2 - 5 } & Pengulangan & $\begin{array}{l}\text { Gerakan lebih } \\
\text { banyak jeda }\end{array}$ & $\begin{array}{l}\text { Gerakan dengan } \\
\text { beberapa jeda }\end{array}$ & $\begin{array}{l}\text { Gerakan } \\
\text { tanpa jeda }\end{array}$ \\
\hline
\end{tabular}

Adapun penilaian tingkat risiko shoulder pada postur pekerja 1 adalah medium dan penilaian tingkat risiko shoulder pada pengulangan adalah medium dapat dilihat pada tabel 6 berikut:

Tabel 6. Penilaian Shoulder Pekerja 1

\begin{tabular}{|l|c|c|c|}
\hline RANK LEVEL & LOW & MED & HIGH \\
\hline Low & 2 & 3 & 4 \\
\hline Medium & 3 & 4 & 5 \\
\hline High & 4 & 5 & 6 \\
\hline
\end{tabular}

Score Shoulder : 4

Arti dari score 4 yaitu diperlukan perbaikan

\section{Penilaian Wrist (pergelangan tangan)}

Aktivitas pengadukan ampas masak dapat dilihat pada gambar 5 berikut:

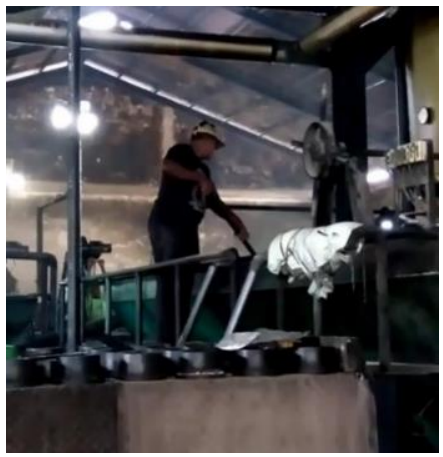

Gambar 5. Penilaian Wrist 
Pengambilannilai tingkat risiko wrist dapat dilihat pada Tabel 7 berikut:

Tabel 7. Penilaian Tingkat Risiko Wrist Pekerja 1

\begin{tabular}{|c|l|l|l|l|}
\hline \multirow{4}{*}{ Wrist } & \multicolumn{4}{|c|}{ Tingkat Risiko } \\
\cline { 3 - 5 } & \multirow{4}{*}{ Postur } & \multicolumn{1}{|c|}{ Low } & \multicolumn{1}{c|}{ Medium } \\
\cline { 3 - 5 } & $\begin{array}{l}\text { Pergelangan } \\
\text { tangan dalam } \\
\text { posisi normal }\end{array}$ & $\begin{array}{l}\text { Pergelangan } \\
\text { tangan ditekuk } \\
\text { keatas atau } \\
\text { ditekuk kebawah }\end{array}$ & $\begin{array}{l}\text { Pergelangan } \\
\text { tangan yang } \\
\text { ekstrim ditekuk } \\
\text { keatas atau } \\
\text { kebawah dengan } \\
\text { memutar }\end{array}$ \\
\cline { 3 - 6 } & Pengulangan & $\begin{array}{l}\text { 6-10 kali } \\
\text { pengulangan }\end{array}$ & $\begin{array}{l}\text { 11-20 kali } \\
\text { pengulangan }\end{array}$ & $\begin{array}{l}\text { Lebih dari 20 kali } \\
\text { permenit }\end{array}$ \\
\hline
\end{tabular}

Penilaian tingkat risiko wrist pada postur pekerja 1 adalah medium dan penilaian tingkat risiko wrist pada pengulangan adalah medium dapat dilihat pada tabel 8 berikut:

Tabel 8. Penilaian Wrist Pekerja 1

\begin{tabular}{|l|c|c|c|}
\hline RANK LEVEL & LOW & MED & HIGH \\
\hline Low & 2 & 3 & 4 \\
\hline Medium & 3 & 4 & 5 \\
\hline High & 4 & 5 & 6 \\
\hline
\end{tabular}

Score wrist : 4

Arti dari score 4 yaitu diperlukan perbaikan

\section{Penilaian Back (punggung)}

Aktivitas pengadukan ampas masak dapat dilihat pada Gambar 6 berikut:

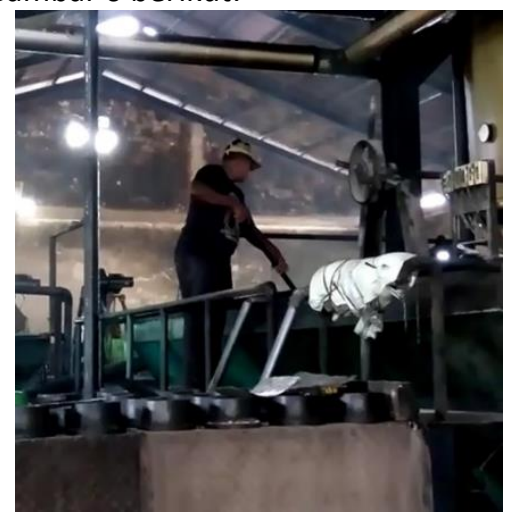

Gambar 6. Penilaian Back

Cara pengambilan nilai tingkat risiko back dapat dilihat pada Tabel 9 berikut:

Tabel 9. Penilaian Tingkat Risiko Back Pekerja 1

\begin{tabular}{|c|l|l|l|l|}
\hline \multirow{4}{*}{ Back } & \multicolumn{4}{|c|}{ Tingkat Risiko } \\
\cline { 2 - 5 } & \multirow{2}{*}{ Postur } & $\begin{array}{l}\text { Low } \\
\text { Punggung di } \\
\text { posisi natural }\end{array}$ & $\begin{array}{l}\text { Punggug ditekuk } \\
\text { kedepan }\end{array}$ & $\begin{array}{l}\text { Punggung } \\
\text { ditekuk ekstrim } \\
\text { kedepan }\end{array}$ \\
\cline { 2 - 5 } & Pengulangan & $\begin{array}{l}0-3 \text { kali } \\
\text { permenit }\end{array}$ & $\begin{array}{l}\text { 4-8 kali } \\
\text { permenit }\end{array}$ & $\begin{array}{l}\text { 9- 20 kali } \\
\text { permenit }\end{array}$ \\
\hline
\end{tabular}

Adapun penilaian tingkat risiko back pada postur pekerja 1 adalah medium dan penilaian tingkat risiko back pada pengulangan adalah medium dapat dilihat pada tabel 10 berikut:

Tabel 10. Penilaian Back Pekerja 1

\begin{tabular}{|l|c|c|c|}
\hline RANK LEVEL & LOW & MED & HIGH \\
\hline Low & 2 & 3 & 4 \\
\hline Medium & 3 & 4 & 5 \\
\hline High & 4 & 5 & 6 \\
\hline
\end{tabular}

Score back : 4

Arti dari score 4 yaitu diperlukan perbaikan

\section{Penilaian Neck (leher)}

Aktivitas pengadukan ampas masak dapat dilihat pada Gambar 7 berikut:

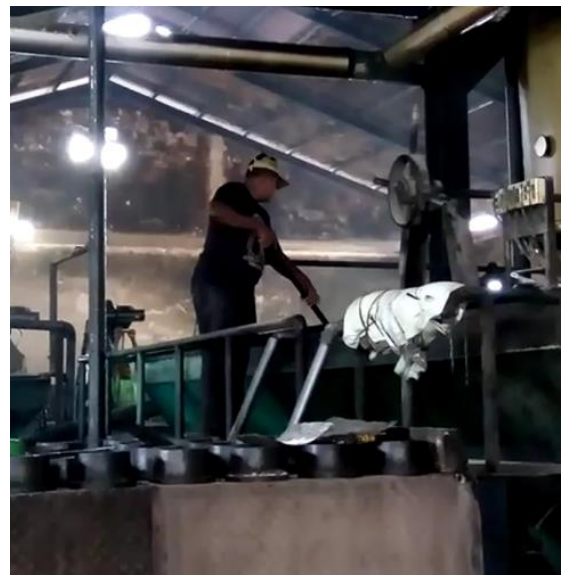

Gambar 7. Penilaian Neck

Cara pengambilan nilai tingkat risiko neck dapat dilihat pada tabel 11 berikut:

Tabel 11. Penilaian Tingkat Risiko Neck Pekerja 1

\begin{tabular}{|c|c|l|l|l|}
\hline \multirow{4}{*}{ Neck } & \multicolumn{4}{|c|}{ Tingkat Risiko } \\
\cline { 2 - 5 } & \multirow{2}{*}{ Postur } & \multicolumn{1}{|c|}{ Low } & \multicolumn{1}{c|}{ Medium } & \multicolumn{1}{c|}{ High } \\
\cline { 2 - 5 } & $\begin{array}{l}\text { Leher di posisi } \\
\text { normal dengan } \\
\text { sedikit tekukan }\end{array}$ & $\begin{array}{l}\text { Leher ditekuk } \\
\text { kedepan }\end{array}$ & $\begin{array}{l}\text { Leher ditekuk } \\
\text { ekstrim kedepan }\end{array}$ \\
\cline { 2 - 5 } & Pengulangan & $\begin{array}{l}\text { Gerakan lebih } \\
\text { banyak jeda }\end{array}$ & $\begin{array}{l}\text { Gerakan dengan } \\
\text { beberapa jeda }\end{array}$ & $\begin{array}{l}\text { Gerakan tanpa } \\
\text { jeda }\end{array}$ \\
\hline
\end{tabular}

Penilaian tingkat risiko neck pada postur pekerja 1 adalah medium dan penilaian tingkat risiko neck pada pengulangan adalah medium. Penilaian resiko dapat dilihat pada tabel 12 berikut:

Tabel 12. Penilaian Neck Pekerja 1

\begin{tabular}{|l|c|c|c|}
\hline RANK LEVEL & LOW & MED & HIGH \\
\hline Low & 2 & 3 & 4 \\
\hline Medium & 3 & 4 & 5 \\
\hline High & 4 & 5 & 6 \\
\hline
\end{tabular}

Score neck: 4

Arti dari score 4 yaitu diperlukan perbaikan

\section{Penilaian Leg (kaki)}

Aktivitas pengadukan ampas masak dapat dilihat pada Gambar 8 berikut: 


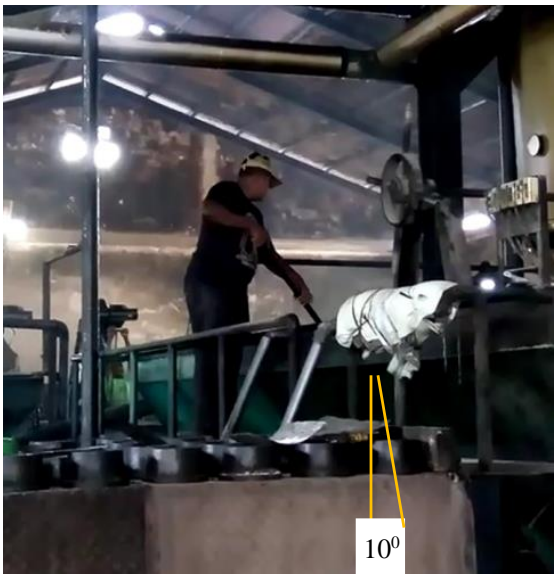

Gambar 8. Penilaian Leg

Cara pengambilan nilai tingkat risiko leg dapat dilihat pada tabel 13 berikut:

Tabel 13. Penilaian Tingkat Risiko Leg Pekerja 1

\begin{tabular}{|c|c|l|l|l|}
\hline \multirow{4}{*}{ Leg } & \multicolumn{3}{|c|}{ Tingkat Risiko } \\
\cline { 2 - 5 } & \multirow{3}{*}{ Postur } & \multicolumn{1}{|c|}{ Low } & \multicolumn{1}{c|}{ Medium } & \multicolumn{1}{c|}{ High } \\
\cline { 3 - 5 } & & $\begin{array}{l}\text { Kaki di posisi } \\
\text { normal }\end{array}$ & $\begin{array}{l}\text { Kaki agak menekuk } \\
\text { kedepan }\end{array}$ & $\begin{array}{l}\text { Kaki terlalu } \\
\text { menekuk kedepan }\end{array}$ \\
\hline
\end{tabular}

Penilaian tingkat risiko leg pada postur pekerja 1 adalah medium dapat dilihat pada tabel 14 berikut:

Tabel 14. Penilaian Leg Pekerja 1

\begin{tabular}{|l|c|c|c|}
\hline RANK LEVEL & LOW & MED & HIGH \\
\hline Low & 2 & 3 & 4 \\
\hline Medium & 3 & 4 & 5 \\
\hline High & 4 & 5 & 6 \\
\hline
\end{tabular}

Score leg : 4

Arti dari score 4 yaitu diperlukan perbaikan

\section{Penilaian Forceful ( angkat beban)}

Aktivitas pengadukan ampas masak dapat dilihat pada Gambar 9 berikut:

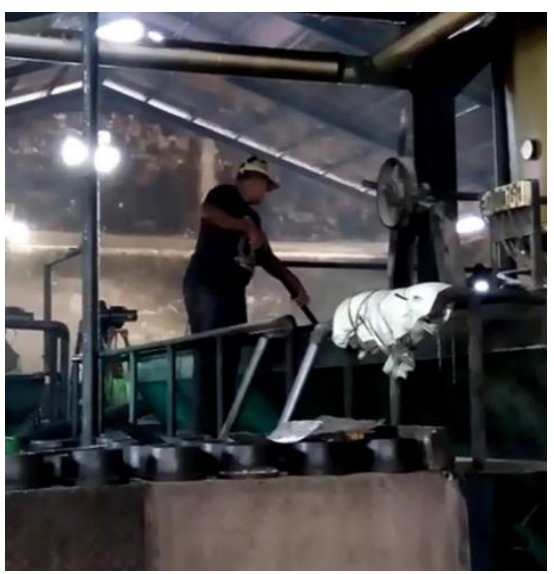

Gambar 9. Penilaian Forceful

Pengambilan nilai tingkat risiko forceful dapat dilihat pada

tabel 15 berikut:
Tabel 15. Penilaian Tingkat Risiko Forceful Pekerja 1

\begin{tabular}{|c|c|l|l|l|}
\hline \multirow{4}{*}{ Forceful } & \multicolumn{4}{|c|}{ Tingkat Risiko } \\
\cline { 3 - 5 } & \multirow{3}{*}{ Postur } & \multicolumn{1}{|c|}{ Low } & \multicolumn{1}{|c|}{ Medium } & \multicolumn{1}{|c|}{ High } \\
\cline { 3 - 5 } & & Mengangkat & Mengangkat & Mengangkat \\
& $0-5 \mathrm{~kg}$ & $5-10 \mathrm{~kg}$ & lebih dari $10 \mathrm{~kg}$ \\
\hline
\end{tabular}

Penilaian tingkat risiko forceful pada postur pekerja 1 adalah low dapat dilihat pada tabel 16 berikut:

Tabel 16. Penilaian Forceful Pekerja 1

\begin{tabular}{|l|c|c|c|}
\hline RANK LEVEL & LOW & MED & HIGH \\
\hline Low & 2 & 3 & 4 \\
\hline Medium & 3 & 4 & 5 \\
\hline High & 4 & 5 & 6 \\
\hline
\end{tabular}

Score forceful : 2

Arti dari sore 2 yaitu mungkin diperlukan perbaikan

\section{Penilaian Vibration (getaran)}

Cara pengambilan nilai tingkat risiko vibration dapat dilihat pada tabel 17 berikut:

Tabel 17. Penilaian Tingkat Risiko Vibration Pekerja 1

\begin{tabular}{|c|c|l|l|l|}
\hline \multirow{3}{*}{ Vibration } & \multicolumn{4}{|c|}{ Tingkat Risiko } \\
\cline { 3 - 5 } & \multirow{3}{*}{ Postur } & \multicolumn{1}{|c|}{ Low } & \multicolumn{1}{|c|}{ Medium } & High \\
\cline { 3 - 5 } & & $\begin{array}{l}\text { Menggunakan alat } \\
<2 \text { jam perhari }\end{array}$ & $\begin{array}{l}\text { Menggunakan alat } \\
2<4 \text { jam perhari }\end{array}$ & $\begin{array}{l}\text { Mengunakan alat lebih } \\
\text { dari 4 jam perhari }\end{array}$ \\
\hline
\end{tabular}

Adapun penilaian tingkat risiko vibration pada postur pekerja 1 adalah low dapat dilihat pada tabel 18 berikut:

Tabel 18. Penilaian Vibration Pekerja 1

\begin{tabular}{|l|c|c|c|}
\hline \multicolumn{1}{|c|}{ RANK LEVEL } & LOW & MED & HIGH \\
\hline Low & 2 & 3 & 4 \\
\hline Medium & 3 & 4 & 5 \\
\hline High & 4 & 5 & 6 \\
\hline
\end{tabular}

Score vibration : 2

Arti dari score 2 yaitu mungkin diperlukan perbaikan

\section{Penilaian Contact Stress}

Cara pengambilan nilai tingkat risiko contact stress dapat dilihat pada tabel 19 berikut:

Tabel 19. Penilaian Tingkat Contact Stress Pekerja 1

\begin{tabular}{|c|c|c|l|l|}
\hline \multirow{4}{*}{\begin{tabular}{c} 
Contact \\
\cline { 3 - 5 } Stress
\end{tabular}} & \multicolumn{4}{|c|}{ Tingkat Risiko } \\
\cline { 3 - 5 } & Postur & \multicolumn{1}{|c|}{ Medium } & \multicolumn{1}{c|}{ High } \\
\cline { 3 - 5 } & & $\begin{array}{l}\text { Menggunakan } \\
\text { pelindung tangan }\end{array}$ & $\begin{array}{l}\text { Menggunakan sebelah } \\
\text { pelindung tangan }\end{array}$ & $\begin{array}{l}\text { Tidak pernah } \\
\text { menggunakan pelindung } \\
\text { tangan }\end{array}$ \\
\hline
\end{tabular}

Adapun penilaian tingkat risiko contact stress pada postur pekerja 1 adalah high dapat dilihat pada tabel 20 berikut: 
Tabel 20. Penilaian Contact Stress Pekerja 1

\begin{tabular}{|l|c|c|c|}
\hline RANK LEVEL & LOW & MED & HIGH \\
\hline Low & 2 & 3 & 4 \\
\hline Medium & 3 & 4 & 5 \\
\hline High & 4 & 5 & 6 \\
\hline
\end{tabular}

Score Contact Stress : 6

Arti dari score 6 yaitu segera diperlukan perbaikan

\section{Penilaian Task Duration}

Cara pengambilan nilai tingkat risiko contact stress dapat dilihat pada tabel 21 berikut:

Tabel 21. Penilaian Risiko Task Duration Pekerja 1

\begin{tabular}{|c|c|c|c|c|}
\hline \multirow{3}{*}{$\begin{array}{c}\text { Task } \\
\text { Duration }\end{array}$} & \multicolumn{4}{|c|}{ Tingkat Risiko } \\
\hline & & Low & Medium & High \\
\hline & Postur & $\begin{array}{l}\text { Tugas }<2 \text { jam } \\
\text { perhari }\end{array}$ & $\begin{array}{l}\text { Tugas 2-4 jam } \\
\text { perhari }\end{array}$ & $\begin{array}{l}\text { Tugas }>4 \text { jam } \\
\text { perhari }\end{array}$ \\
\hline
\end{tabular}

Adapun penilaian tingkat risiko task duration pada postur pekerja 1 adalah high dapat dilihat pada tabel 22 berikut:

Tabel 22. Penilaian Task Duration Pekerja 1

\begin{tabular}{|l|c|c|c|}
\hline \multicolumn{1}{|c|}{ RANK LEVEL } & LOW & MED & HIGH \\
\hline Low & 2 & 3 & 4 \\
\hline Medium & 3 & 4 & 5 \\
\hline High & 4 & 5 & 6 \\
\hline
\end{tabular}

Score task duration : 6

Arti dari score 6 yaitu segera diperlukan perbaikan

\section{Penilaian Aktivitas Pengadukan Ampas Masak Stasiun 2} Adapun penilaian postur kerja pada aktivitas pengadukan ampas masak berikut:

\section{Penilaian Shoulder (bahu)}

Aktivitas pengadukan ampas masak dapat dilihat pada gambar 10 berikut:

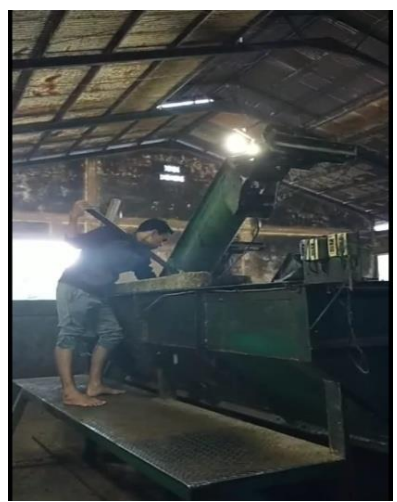

Gambar 10. Penilaian Shoulder

Pengambilan nilai tingkat risiko shoulder dapat dilihat pada Tabel 23 berikut:
Tabel 23. Penilaian Tingkat Risiko Shoulder Pekerja 2

\begin{tabular}{|l|l|l|l|l|}
\hline \multirow{4}{*}{ Shoulder } & \multicolumn{4}{|c|}{ Tingkat Risiko } \\
\cline { 2 - 5 } & \multirow{2}{*}{ Postur } & \multicolumn{1}{|c|}{ Low } & \multicolumn{1}{c|}{ Medium } \\
\cline { 2 - 5 } & $\begin{array}{l}\text { Bahu diposisi } \\
\text { netral }\end{array}$ & Bahu ditekuk & $\begin{array}{l}\text { Bahu ditekuk } \\
\text { keatas }\end{array}$ \\
\cline { 2 - 5 } & Pengulangan & $\begin{array}{l}\text { Gerakan lebih } \\
\text { banyak jeda }\end{array}$ & $\begin{array}{l}\text { Gerakan dengan } \\
\text { beberapa jeda }\end{array}$ & $\begin{array}{l}\text { Gerakan } \\
\text { tanpa jeda }\end{array}$ \\
\hline
\end{tabular}

Penilaian tingkat risiko shoulder pada postur pekerja 2 adalah medium dan penilaian tingkat risiko shoulder pada pengulangan adalah medium dapat dilihat pada tabel 24 berikut:

Tabel 24. Penilaian Shoulder Pekerja 2

\begin{tabular}{|l|c|c|c|}
\hline \multicolumn{1}{|c|}{ RANK LEVEL } & LOW & MED & HIGH \\
\hline Low & 2 & 3 & 4 \\
\hline Medium & 3 & 4 & 5 \\
\hline High & 4 & 5 & 6 \\
\hline
\end{tabular}

Score Shoulder : 4

Arti dari score 4 yaitu diperlukan perbaikan

\section{Penilaian Wrist (pergelangan tangan)}

Aktivitas pengadukan ampas masak dapat dilihat pada gambar 11 berikut:

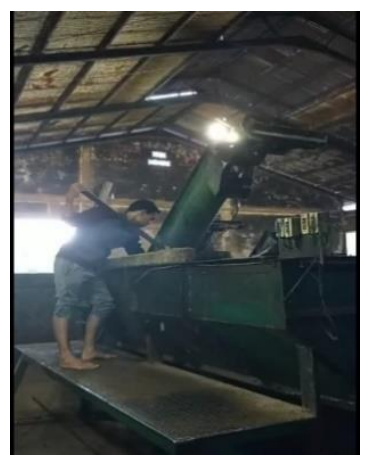

Gambar 11. Penilaian Wrist

Cara pengambilan nilai tingkat risiko wrist dapat dilihat pada Tabel 25 berikut:

Tabel 25. Penilaian Tingkat Risiko Wrist Pekerja 2

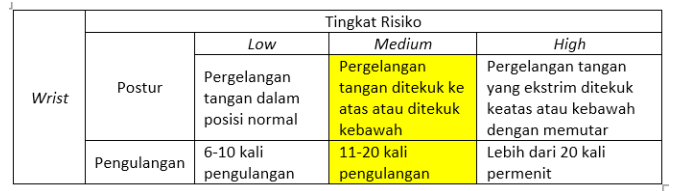

Adapun penilaian tingkat risiko wrist pada postur pekerja 2 adalah medium dan penilaian tingkat risiko wrist pada pengulangan adalah medium dapat dilihat pada tabel 26 berikut:

Tabel 26. Penilaian Wrist Pekerja 2

\begin{tabular}{|l|c|c|c|}
\hline \multicolumn{1}{|c|}{ RANK LEVEL } & LOW & MED & HIGH \\
\hline Low & 2 & 3 & 4 \\
\hline Medium & 3 & 4 & 5 \\
\hline High & 4 & 5 & 6 \\
\hline
\end{tabular}

Score wrist : 4

Arti dari score 4 yaitu diperlukan perbaikan 


\section{Penilaian Back (punggung)}

Aktivitas pengadukan ampas masak dapat dilihat pada Gambar 12 berikut:

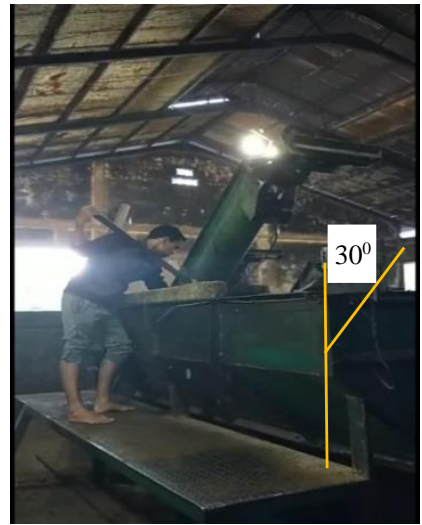

Gambar 12. Penilaian back

Cara pengambilan nilai tingkat risiko back dapat dilihat pada Tabel 27 berikut:

Tabel 27. Penilaian Tingkat Risiko Back Pekerja 2

\begin{tabular}{|c|c|l|l|l|}
\hline \multirow{4}{*}{ Back } & \multicolumn{4}{|c|}{ Tingkat Risiko } \\
\cline { 2 - 5 } & \multirow{3}{*}{ Postur } & \multicolumn{1}{|c|}{ Low } & \multicolumn{1}{c|}{ Medium } & \multicolumn{1}{c|}{ High } \\
\cline { 3 - 5 } & & $\begin{array}{l}\text { Punggung di } \\
\text { posisi natural }\end{array}$ & $\begin{array}{l}\text { Punggug ditekuk } \\
\text { kedepan }\end{array}$ & $\begin{array}{l}\text { Punggung ditekuk } \\
\text { ekstrim kedepan }\end{array}$ \\
\cline { 2 - 5 } & \multirow{2}{*}{ Pengulangan } & $\begin{array}{l}0-3 \text { kali } \\
\text { permenit }\end{array}$ & $\begin{array}{l}\text { 4-8 kali } \\
\text { permenit }\end{array}$ & $\begin{array}{l}\text { 9-20 kali } \\
\text { permenit }\end{array}$ \\
\hline
\end{tabular}

Adapun penilaian tingkat risiko back pada postur pekerja 2 adalah high dan penilaian tingkat risiko back pada pengulangan adalah high dapat dilihat pada tabel 28 berikut:

Tabel 28. Penilaian Back Pekerja 2

\begin{tabular}{|l|c|c|c|}
\hline RANK LEVEL & LOW & MED & HIGH \\
\hline Low & 2 & 3 & 4 \\
\hline Medium & 3 & 4 & 5 \\
\hline High & 4 & 5 & 6 \\
\hline
\end{tabular}

Score back : 4 ( Sangat Diperlukan Perbaikan)

\section{Penilaian Neck (leher)}

Aktivitas pengadukan ampas masak dapat dilihat pada Gambar 13 berikut:

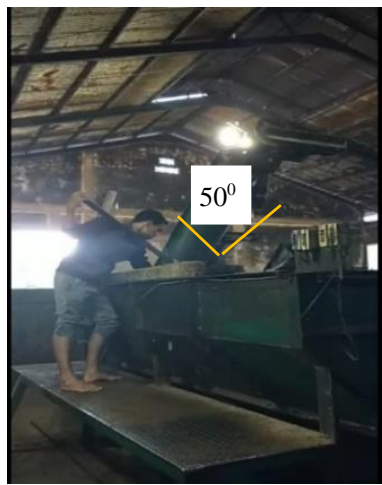

Gambar 13. Penilaian Neck

Pengambilan nilai tingkat risiko neck dapat dilihat pada tabel 29 berikut:
Tabel 29. Penilaian Tingkat Risiko Neck Pekerja 2

\begin{tabular}{|c|l|l|l|l|}
\hline \multirow{4}{*}{ Neck } & \multicolumn{4}{|c|}{ Tingkat Risiko } \\
\cline { 2 - 5 } & \multirow{2}{*}{ Postur } & \multicolumn{1}{|c|}{ Low } & \multicolumn{1}{c|}{ Medium } & \multicolumn{1}{c|}{ High } \\
\cline { 2 - 5 } & $\begin{array}{l}\text { Leher di posisi } \\
\text { normal dengan } \\
\text { sedikit tekukan }\end{array}$ & $\begin{array}{l}\text { Leher ditekuk } \\
\text { kedepan }\end{array}$ & $\begin{array}{l}\text { Leher ditekuk } \\
\text { ektrim kedepan }\end{array}$ \\
\cline { 2 - 5 } & Pengulangan & $\begin{array}{l}\text { Gerakan lebih } \\
\text { banyak jeda }\end{array}$ & $\begin{array}{l}\text { Gerakan dengan } \\
\text { beberapa jeda }\end{array}$ & $\begin{array}{l}\text { Gerakan tanpa } \\
\text { jeda }\end{array}$ \\
\hline
\end{tabular}

Adapun penilaian tingkat risiko neck pada postur pekerja 2 adalah medium dan penilaian tingkat risiko neck pada pengulangan adalah medium dapat dilihat pada tabel 30 berikut:

Tabel 30. Penilaian Neck Pekerja 2

\begin{tabular}{|l|c|c|c|}
\hline RANK LEVEL & LOW & MED & HIGH \\
\hline Low & 2 & 3 & 4 \\
\hline Medium & 3 & 4 & 5 \\
\hline High & 4 & 5 & 6 \\
\hline
\end{tabular}

Score neck : 4 , diperlukan perbaikan

\section{Penilaian Leg (kaki)}

Adapun gambar aktivitas pengadukan ampas masak dapat dilihat pada Gambar 14 berikut:

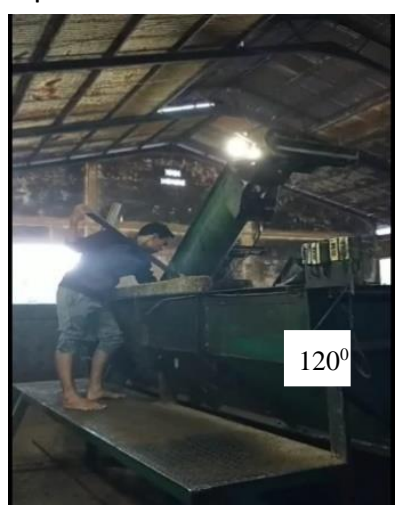

Gambar 14. Penilaian Leg

Pengambilan nilai tingkat risiko leg dapat dilihat pada Tabel 31 berikut:

Tabel 31. Penilaian Tingkat Risiko Leg Pekerja 2

\begin{tabular}{|c|c|l|l|l|}
\hline \multirow{4}{*}{ Leg } & \multicolumn{4}{|c|}{ Tingkat Risiko } \\
\cline { 3 - 5 } & \multirow{3}{*}{ Postur } & \multicolumn{1}{|c|}{ Low } & \multicolumn{1}{c|}{ Medium } & \multicolumn{1}{c|}{ High } \\
\cline { 3 - 5 } & & $\begin{array}{l}\text { Kaki di posisi } \\
\text { normal }\end{array}$ & $\begin{array}{l}\text { Kaki agak menekuk } \\
\text { kedepan }\end{array}$ & $\begin{array}{l}\text { Kaki terlalu } \\
\text { menekuk kedepan }\end{array}$ \\
\hline
\end{tabular}

Adapun penilaian tingkat risiko leg pada postur pekerja 2 adalah high dapat dilihat pada tabel 32 berikut:

Tabel 32. Penilaian Leg Pekerja 2

\begin{tabular}{|l|c|c|c|}
\hline \multicolumn{1}{|c|}{ RANK LEVEL } & LOW & MED & HIGH \\
\hline Low & 2 & 3 & 4 \\
\hline Medium & 3 & 4 & 5 \\
\hline High & 4 & 5 & 6 \\
\hline
\end{tabular}

Score leg : 6

Arti dari score 6 yaitu segera diperlukan perbaikan 


\section{Penilaian Forceful ( angkat beban)}

Aktivitas pengadukan ampas masak dapat dilihat pada Gambar 15 berikut:

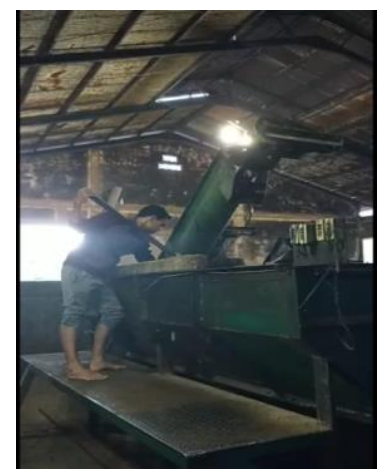

Gambar 15. Penilaian Forceful

Pengambilan nilai tingkat risiko forceful dapat dilihat pada tabel 33 berikut:

Tabel 33. Penilaian Tingkat Risiko Forceful Pekerja 2

\begin{tabular}{|l|l|l|l|l|}
\hline \multirow{3}{*}{ Forceful } & \multicolumn{4}{|c|}{ Tingkat Risiko } \\
\cline { 2 - 5 } & \multirow{3}{*}{ Postur } & \multicolumn{1}{|c|}{ Low } & \multicolumn{1}{c|}{ Medium } & \multicolumn{1}{c|}{ High } \\
\cline { 3 - 5 } & & Mengangkat & Mengangkat & Mengangkat \\
& $0-5 \mathrm{~kg}$ & $5-10 \mathrm{~kg}$ & lebih dari $10 \mathrm{~kg}$ \\
\hline
\end{tabular}

Adapun penilaian tingkat risiko forceful pada postur pekerja 2 adalah low dapat dilihat pada tabel 34 berikut:

Tabel 34. Penilaian forceful Pekerja 2

\begin{tabular}{|l|c|c|c|}
\hline RANK LEVEL & LOW & MED & HIGH \\
\hline Low & 2 & 3 & 4 \\
\hline Medium & 3 & 4 & 5 \\
\hline High & 4 & 5 & 6 \\
\hline
\end{tabular}

Score forceful : 2

artinya mungkin diperlukan perbaikan

\section{Penilaian Vibration (getaran)}

Pengambilan nilai tingkat risiko vibration dapat dilihat pada tabel 35

Tabel 35. Penilaian Tingkat Risiko Vibration Pekerja 2

\begin{tabular}{|c|c|l|l|l|}
\hline \multirow{4}{*}{ Vibration } & \multicolumn{4}{|c|}{ Tingkat Risiko } \\
\cline { 2 - 5 } & Postur & \multicolumn{1}{|c|}{ Medium } & \multicolumn{1}{c|}{ High } \\
\cline { 3 - 5 } & $\begin{array}{l}\text { Menggunakan alat } \\
<2 \text { jam perhari }\end{array}$ & $\begin{array}{l}\text { Menggunakan alat } \\
2<4 \text { jam perhari }\end{array}$ & $\begin{array}{l}\text { Mengunakan alat } \\
\text { lebih dari 4 jam } \\
\text { perhari }\end{array}$ \\
\hline
\end{tabular}

Adapun penilaian tingkat risiko vibration pada postur pekerja 2 adalah low dapat dilihat pada tabel 36 berikut:

Tabel 36. Penilaian Vibration Pekerja 2

\begin{tabular}{|l|c|c|c|}
\hline RANK LEVEL & LOW & MED & HIGH \\
\hline Low & 2 & 3 & 4 \\
\hline Medium & 3 & 4 & 5 \\
\hline High & 4 & 5 & 6 \\
\hline
\end{tabular}

Score vibration 2

artinya mungkin diperlukan perbaikan

\section{Penilaian Contact Stress}

Pengambilan nilai tingkat risiko contact stress dapat dilihat pada tabel 37 berikut:

Tabel 37. Penilaian Tingkat Risiko Contact Stress Pekerja 2

\begin{tabular}{|l|l|l|l|l|}
\hline \multirow{3}{*}{\begin{tabular}{l} 
Contact \\
\cline { 2 - 5 } Stress
\end{tabular}} & \multirow{3}{*}{ Postur } & \multicolumn{1}{|c|}{ Low } & \multicolumn{1}{|c|}{ Medium } & \multicolumn{1}{|c|}{ High } \\
\cline { 3 - 5 } & $\begin{array}{l}\text { Menggunakan } \\
\text { semua pelindung } \\
\text { tangan }\end{array}$ & $\begin{array}{l}\text { Menggunakan } \\
\text { sebelah pelindung } \\
\text { tangan }\end{array}$ & $\begin{array}{l}\text { Tidak pernah } \\
\text { menggunakan } \\
\text { pelindung tangan }\end{array}$ \\
\hline
\end{tabular}

Adapun penilaian tingkat risiko contact stress pada postur pekerja 2 adalah high dapat dilihat pada tabel 38 berikut:

Tabel 38. Penilaian Contact Stress Pekerja 2

\begin{tabular}{|l|c|c|c|}
\hline RANK LEVEL & LOW & MED & HIGH \\
\hline Low & 2 & 3 & 4 \\
\hline Medium & 3 & 4 & 5 \\
\hline High & 4 & 5 & 6 \\
\hline
\end{tabular}

Score Contact Stress : 6

artinya diperlukan perbaikan segera

\section{Penilaian Task Duration}

Pengambilan nilai tingkat risiko contact stress dapat dilihat pada tabel 39 berikut:

Tabel 39. Penilaian Risiko Task Duration Pekerja 2

\begin{tabular}{|c|c|c|c|c|}
\hline \multirow{3}{*}{$\begin{array}{l}\text { Task } \\
\text { Duration }\end{array}$} & \multicolumn{4}{|c|}{ Tingkat Risiko } \\
\hline & & Low & Medium & High \\
\hline & Postur & $\begin{array}{l}\text { Tugas }<2 \text { jam } \\
\text { perhari }\end{array}$ & $\begin{array}{l}\text { Tugas 2-4 jam } \\
\text { perhari }\end{array}$ & $\begin{array}{l}\text { Tugas lebih dari } 4 \\
\text { jam perhari }\end{array}$ \\
\hline
\end{tabular}

Adapun penilaian tingkat risiko task duration pada postur pekerja 2 adalah high dapat dilihat pada tabel 40 berikut:

Tabel 40. Penilaian Task Duration Pekerja 2

\begin{tabular}{|l|c|c|c|}
\hline \multicolumn{1}{|c|}{ RANK LEVEL } & LOW & MED & HIGH \\
\hline Low & 2 & 3 & 4 \\
\hline Medium & 3 & 4 & 5 \\
\hline High & 4 & 5 & 6 \\
\hline
\end{tabular}

Score task duration: 6

Arti dari score 6 artinya diperlukan perbaikan segera

\section{Rekapitulasi Hasil Penilaian WERA}

Rekapitulasi hasil penilaian postur kerja pada dua stasiun kerja dapat dilihat pada Tabel 41 berikut:

Tabel 41. Hasil Penilaian Postur Kerja Petugas Pengadukan Ampas Masak

\begin{tabular}{|c|c|c|c|c|c|c|c|c|c|c|c|c|}
\hline \multirow[t]{2}{*}{ No } & \multirow[b]{2}{*}{ Aktivitas } & \multicolumn{9}{|c|}{ Indikator Fisik } & \multirow[b]{2}{*}{ Skor } & \multirow{2}{*}{$\begin{array}{l}\text { Tingkat } \\
\text { Risiko }\end{array}$} \\
\hline & & 1 & 2 & 3 & 4 & 5 & 6 & 7 & 8 & 9 & & \\
\hline 1 & $\begin{array}{l}\text { Pengadukan } \\
\text { ampas masak } \\
\text { pekerja 1 }\end{array}$ & 4 & 4 & 4 & 4 & 4 & 2 & 2 & 6 & 6 & 36 & Medium \\
\hline 2 & $\begin{array}{l}\text { Pengadukan } \\
\text { ampas masak } \\
\text { pekerja } 2\end{array}$ & 4 & 4 & 4 & 4 & 6 & 2 & 2 & 6 & 6 & 38 & Medium \\
\hline
\end{tabular}


Berdasarkan hasil pengolahan menggunakan metode WERA, di dapatkan tingkat risiko pada tiap-tiap aktivitas dimana aktivitas 1 jumlah skor adalah 36 dan aktivitas 2 jumlah skor adalah 38. Hal tersebut mengidentifikasikan bahwa postur kerja petugas pengadukan ampas masak berada pada tingkat risiko medium.

\section{Analisis}

Pekerja pertama pengadukan ampas masak yang di nilai berdasarkan 9 indikator metode workplace ergonomic risk assesment didapatkan score 4 pada bahu yang menunjukkan terdapat risiko karena bahu di tekuk, pergelangan tangan mendapat score 4 karena melakukan pengulangan 11-20 kali, punggung mendapat score 4 yang menunjukkan risiko karena punggung ditekuk kedepan, leher mendapat score 4 karena leher di posisi normal dengan sedikit tekukan, kaki mendapat score 4 yang menunjukkan risiko karena kaki ditekuk kedepan, beban kerja mendapat score 2 karena mengangkat beban $0-5 \mathrm{~kg}$, getaran mendapat score 2 karena tidak mengangkat yang mempunyai getaran, kontak stres mendapat score 6 karena tidak pernah menggunakan pelindung tangan, jam kerja mendapat score 6 yang menunjukkan risiko karena mempunyai jam keja lebih dari 4 jam perhari. Aktivitas pengadukan ampas masak pada stasiun pertama mendapat total score 36 yang mengindikasikan tingkat risiko pekerja adalah medium.

Pekerja kedua pengadukan ampas masak yang di nilai berdasarkan 9 indikator metode workplace ergonomic risk assesment didapatkan score 4 pada bahu yang menunjukkan terdapat risiko karena bahu di tekuk, pergelangan tangan mendapat score 4 karena melakukan pengulangan 11-20 kali, punggung mendapat score 4 yang menunjukkan risiko karena punggung ditekuk kedepan, leher mendapat score 4 karena leher di posisi normal dengan sedikit tekukan, kaki mendapat score 6 yang menunjukkan risiko karena kaki ditekuk ekstrim kedepan, beban kerja mendapat score 2 karena mengangkat beban $0-5 \mathrm{~kg}$, getaran mendapat score 2 karena tidak mengangkat yang mempunyai getaran, kontak stres mendapat score 6 karena tidak pernah menggunakan pelindung tangan, jam kerja mendapat score 6 yang menunjukkan risiko karna mempunyai jam keja lebih dari 4 jam perhari. Aktivitas pengadukan ampas masak pada stasiun kedua mendapat total score 38 yang mengindikasikan tingkat risiko pekerja adalah medium.

\section{Kesimpulan}

Berdasarkan pendekatan dengan metode WERA maka didapatkan hasil pengkuran pada aktivitas pengadukan ampas masak pada stasiun 1 yaitu 36 yang digolongkan pada tingkat risiko medium score tertinggi terdapat pada bahu, pergelangan tangan, punggung, kaki, penggunaan pelindung dan jam kerja. Pada aktivitas pengadukan ampas masak pada stasiun ke 2 didapatkan score 38 digolongkan pada tingkat risiko medium score tertinggi terdapat pada bahu, pergelangan tangan, punggung, kaki, penggunaan pelindung dan jam kerja. Berdasarkan hasil pengkuran yang diperoleh pada 2 stasiun kerja dapat disimpulkan bahwa pengukuran postur kerja menggunakan metode WERA berada pada tingkat risiko medium. Tingkat risiko tersebut mengindikasikan bahwa dibutuhkan investigasi lebih lanjut dan perbaikan pada sistem kerja. Faktor risiko paling tinggi dari tiap-tiap divisi berbeda, tergantung dari aktivitas pekerjaan yang dilakukan. Usulan perbaikan di berikan berdasarkan faktor risiko paling tinggi dari tiap-tiap divisi.

\section{Daftar Pustaka}

[1 ] Rochman, T., Astuti, R.D., \& Setyawan F. D. (2012). Perancangan Ulang Fasilitas Fisik Kerja Operator di Stasiun Penjilidan pada Industri Percetakan Berdasarkan Prinsip Ergonomi. 11(1), 1-8.

[2 ] Sulaiman, F., \& Sari, Y. P. (2016). Analisis Postur Kerja Pekerja Proses Pengesahan. 03, 16-25.

[3 ] Susihono, Wahyu. 2012. Perbaikan Postur Kerja Untuk Mengurangi Keluhan Musculoskeletal Dengan Pendekatan Metode OWAS (Studi Kasus Di UD. Rizki Ragil Jaya - Kota Cilegon). Spektrum Industri Fakultas Teknik Universitas Sultan Ageng Tirtayasa, Serang.

[4 ] Andrian, Deni. 2013. Pengukuran Tingkat Ergonomi Secara Biomekanika Pada Pekerja Pengangkutan Semen (Studi Kasus: PT. Semen Baturaja). Laporan Kerja Praktek Fakultas Teknik Universitas Binadarma, Palembang.

[5 ] Aliafari, N., Pertiwi, O. R., \&. Anugerah, M. T. (2018). Analisis Eksposur Kerja pada Lini I Produksi Batik Menggunakan Metode Workplace Ergonomic Risk Assessment. 7-8. 